\title{
Immunological response after initiation of second line anti-retroviral therapy in HIV patients
}

\author{
Basavaprabhu Achappa ${ }^{* \dagger}$, Keerthi Pillai ${ }^{\dagger}$, John T Ramapuram, Satish B Rao, Deepak R Madi, Unnikrishnan \\ From 17th International Symposium on HIV and Emerging Infectious Diseases (ISHEID) \\ Marseille, France. 23-25 May 2012
}

\section{Introduction}

Treatment with second line ART is initiated when the first line therapy fails. There is less experience with the immunologic response for second-line ART for adults. Hence this study was done to find out the immunological response after initiation of second line ART by analysis of CD4 counts.

\section{Methods}

This retrospective study was conducted in a tertiary level hospital attached to a medical college that caters to a large number of HIV positive patients. The study population for this analysis included all HIV positive individuals who were undergoing second line ART treatment.The data was collected using semi-structured pre-tested proforma from the hospital records of HIV positive individuals. The immunological response after the initiation of second line ART was analyzed using the CD4 cell counts taken at intervals of 3 months and 6 months after the initiation. therapy $(\mathrm{p}=.001$, table 1$)$ and to $54.63 \pm 10.29 \mathrm{~kg}$ at the end of 6 months.

\section{Conclusion}

The CD4 counts increase very significantly within the first 3 months of initiation of second line therapy.The rise in CD4 count between 3 months and 6 months is not as statistically significant as the earlier one. Also, there is significant gain in weight within 6 months of initiation of second line therapy.

Published: 25 May 2012

doi:10.1186/1742-4690-9-S1-P11

Cite this article as: Achappa et al:: Immunological response after initiation of second line anti-retroviral therapy in HIV patients. Retrovirology 2012 9(Suppl 1):P11.

\section{Results}

Out of the 32 patients studied, 27(84.4\%) were males and only $5(15.6 \%)$ were females. Mean age of the patients was $40.56 \pm 6.78$ years. The mean $\mathrm{CD} 4$ value at initiation was $152.35 \pm 142.89$ cells $/ \mu \mathrm{L}$, which significantly increased to $324.43 \pm 163.65$ cells / $\mu$ Lby 3 months after initiation ( $p$ value $=.000)$ and to $348.21 \pm 253.57$ cells $/ \mu$ Lby 6 months after initiation.Around $91.3 \%$ of patients had a baseline CD4 T cell count $<350$ cells L- 6 . After 3 months of therapy, $65.2 \%$ of patients and after 6 months $46.2 \%$ had a baseline CD $4 \mathrm{~T}$ cell count $<350$ cells $/ \mu \mathrm{L}$. The mean weight at initiation was $50.548 \pm 11.37 \mathrm{~kg}$, which very significantly increased to $53.30 \pm 11.1 \mathrm{~kg}$ by 3 months of

\footnotetext{
* Correspondence: bachu1504@gmail.com

+ Contributed equally

Kasturba Medical College, Manipal University, Mangalore, India
}

Submit your next manuscript to BioMed Central and take full advantage of:

- Convenient online submission

- Thorough peer review

- No space constraints or color figure charges

- Immediate publication on acceptance

- Inclusion in PubMed, CAS, Scopus and Google Scholar

- Research which is freely available for redistribution

Submit your manuscript at www.biomedcentral.com/submit 